\title{
Dual EGFR inhibition in combination with anti-VEGF treatment: A phase I clinical trial in non-small cell lung cancer
}

\author{
Gerald S. Falchook ${ }^{1}$, Aung Naing ${ }^{1}$, David S. Hong ${ }^{1}$, Ralph Zinner ${ }^{1}$, Siqing Fu ${ }^{1}$, Sarina \\ A. Piha-Paul ${ }^{1}$, Apostolia M. Tsimberidou ${ }^{1}$, Sonia K. Morgan-Linnell ${ }^{1}$, Yunfang \\ Jiang ${ }^{1}$, Christel Bastida ${ }^{1}$, Jennifer J. Wheler ${ }^{1}$, and Razelle Kurzrock ${ }^{2}$ \\ ${ }^{1}$ Department of Investigational Cancer Therapeutics (Phase I Program), U.T. MD Anderson Cancer Center, Houston, TX \\ ${ }^{2}$ Moores Cancer Center at the University of California, San Diego \\ Correspondence to: Gerald Falchook, email: gfalchoo@mdanderson.org \\ Keywords: Erlotinib, Cetuximab, Bevacizumab, EGFR, VEGF \\ Received: December 06, 2012, Accepted: January 12, 2013, \\ Published: January 14, 2013 \\ Copyright: ( F Falchook et al. This is an open-access article distributed under the terms of the Creative Commons Attribution License, which \\ permits unrestricted use, distribution, and reproduction in any medium, provided the original author and source are credited.
}

\section{ABSTRACT:}

BACKGROUND: Preclinical data indicate EGFR signals through both kinasedependent and independent pathways and that combining a small-molecule EGFR inhibitor, EGFR antibody, and/or anti-angiogenic agent is synergistic in animal models.

METHODS: We conducted a dose-escalation, phase I study combining erlotinib, cetuximab, and bevacizumab. The subset of patients with non-small cell lung cancer (NSCLC) was analyzed for safety and response.

RESULTS: Thirty-four patients with NSCLC (median four prior therapies) received treatment on a range of dose levels. The most common treatment-related grade $\geq 2$ adverse events were rash $(n=14,41 \%)$, hypomagnesemia $(n=9,27 \%)$, and fatigue $(n=5,15 \%)$. Seven patients $(21 \%)$ achieved stable disease (SD) $\geq 6$ months, two achieved a partial response (PR) $(6 \%)$, and two achieved an unconfirmed partial response (UPR) $(6 \%)$ (total $=32 \%)$. We observed SD $\geq 6$ months/PR/uPR in patients who had received prior erlotinib and/or bevacizumab, those with brain metastases, smokers, and patients treated at lower dose levels. Five of 16 patients ( $31 \%)$ with wild-type EGFR experienced SD $\geq 6$ months or uPR. Correlation between grade of rash and rate of SD $\geq 6$ months/PR was observed $(p<0.01)$.

CONCLUSION: The combination of erlotinib, cetuximab, and bevacizumab was well-tolerated and demonstrated antitumor activity in heavily pretreated patients with NSCLC.

\section{INTRODUCTION}

The epidermal growth factor receptor (EGFR) is a receptor tyrosine kinase that plays an important role in tumorigenesis [1], and signals via downstream effectors [2]. EGFR mutations are seen in $\sim 13 \%$ of patients with non-small cell lung cancer (NSCLC) in the United States [3], with a higher incidence in Japanese patients [4], and contribute to the pathogenesis of affected lung tumors. Targeted therapies have shown promise in the treatment of NSCLC, with studies selecting patients for molecular targets faring better in general [5-8]. Erlotinib, an EGFR inhibitor, is approved by the Federal Drug Administration (FDA) to treat locally advanced or metastatic NSCLC [9]. Most responses to erlotinib occur in patients with EGFR mutations [3, 10-12], and both resistant (e.g., L861Q) and sensitive (e.g., exon 18 G719S, exon 19 deletion or exon 21 L858R point mutation) mutations have been identified [12-15]. Cetuximab, a monoclonal antibody to EGFR, has demonstrated efficacy in NSCLC when combined with chemotherapy [16], but is not currently FDA-approved for NSCLC.

Recently, Weihua, et al. [17] discovered that EGFR can maintain cancer cell survival independent of its kinase activity. This kinase-independent pathway operates via increased glucose uptake due to stabilization of the SGLT1 glucose transporter, with a downstream effect of reduced autophagy [17]. Therefore, targeting both kinasedependent and kinase-independent EGFR functions may be a rational treatment strategy. Indeed, studies in animal 
models revealed that combining antibodies and kinase inhibitors was synergistic [18, 19]. Cetuximab blocks receptor activation by interfering with ligand binding, as well as down-regulating EGFR levels and inhibiting cell growth in association with inhibition of ligandindependent EGFR signaling [20, 21]. Therefore, it is plausible that treatment with cetuximab could suppress kinase-independent cell signaling [21].

Angiogenesis also plays an important role in tumor development and metastasis [22], mediated in large part by vascular endothelial growth factor (VEGF) and its receptor VEGFR [23]. Bevacizumab is a recombinant antiVEGF monoclonal antibody FDA-approved for treatment of unresectable, locally-advanced, recurrent, or metastatic NSCLC in combination with paclitaxel and carboplatin [9, 24].

Unfortunately, targeting angiogenesis or EGFR alone does not provide adequate tumor control in many patients [25-27]. Prior studies combining erlotinib and cetuximab or gefitinib and cetuximab failed to demonstrate tumor regressions in patients with lung adenocarcinomas resistant to erlotinib [28] or patients with NSCLC previously treated with platinum-based therapy [29], respectively. In contrast, targeting both VEGF and EGFR pathways demonstrated synergy in vivo [30,31], possibly because resistance to EGFR inhibitors may be mediated at least partly by activating VEGF-dependent signaling as an alternative survival pathway [30, 31]. Furthermore, combining erlotinib and bevacizumab in patients with NSCLC who had not received prior anti-VEGF or antiEGFR treatment, showed response rates (CR/PR) of 18$20 \%[31,32]$ and improved progression-free survival (PFS), but not overall survival (OS) [33].

Here, we report, for the first time, the results of administering dual EGFR inhibitors (erlotinib plus cetuximab) together with an anti-angiogenic agent (bevacizumab) in 34 patients with heavily-pretreated NSCLC.

\section{RESULTS}

\section{Demographics}

Thirty-four patients with NSCLC were enrolled (Table 2). All patients had progressive disease at the time of enrollment. Most patients were heavily pretreated, with a median of four prior therapies (range 1-8). Most patients $(76 \%)$ had adenocarcinoma histology. Thirteen patients $(38 \%)$ were previously treated with erlotinib, and 11 patients $(32 \%)$ had previously received bevacizumab. Three of 19 patients tested (16\%) had EGFR mutations; 19 patients tested for KRAS mutations were all wild-type. The only patient tested for p53 had a mutation (R196*), and two patients out of nine tested had PIK3CA mutations
(E542K and E545K). PTEN expression was tested by immunohistochemistry $(n=3)$ or mutation analysis $(n=2)$, and no aberrations were found.

\section{Adverse Events}

The most common treatment-related grade 2 or higher adverse events were rash $(n=14,41 \%)$, hypomagnesemia $(n=9,26 \%)$, and fatigue $(n=5,15 \%)$ (Table 1). Treatment-related grade 2 hypotension, hemoptysis, neuropathy, vomiting, anorexia, infusion reaction, proteinuria, and grade 3 diarrhea were each observed in only one patient. Two patients experienced dose-limiting toxicity (DLT), including grade 3 rash $(n=1$, dose level 8) and grade 3 bronchospasm $(n=1$, dose level 6). Twenty-four patients (71\%) experienced no drugrelated toxicity higher than grade 1 . Three patients $(9 \%)$ withdrew due to toxicity, including grade 3 bronchospasm in cycle $1(n=1)$, grade 1 diarrhea in cycle $1(n=1)$, and grade 3 fatigue in cycle $4(n=1)$. No deaths resulted from adverse events. The RP2D was level 8, which includes the recommended FDA-approved full dose of each medication [34].

\section{Responses}

All 34 patients are included in the response data (Figure 1). Three patients withdrew before the first restaging assessment due to toxicity, and one patient withdrew early because of financial considerations. These four patients and any patients with clinical progression or new lesions are arbitrarily depicted as $21 \%$ increase (Figure 1) and are considered treatment failures. Four patients $(12 \%)$ achieved a PR (two were unconfirmed PR (uPR)) and received treatment for 4, 6, 10, and 14 months (Table 3, Figure 2). Seven patients (21\%) achieved stable disease (SD) lasting at least 6 months (duration was 6 , $6,7,9,10,12$, and 25 months) (total $\mathrm{SD} \geq 6$ months/PR/ $\mathrm{uPR}=11,(32 \%))$.

\section{Prior EGFR inhibitor or VEGF Inhibitor Therapy and Response}

Of all 34 patients on study, seven patients (21\%) had received prior erlotinib but no prior bevacizumab, five patients $(15 \%)$ had received prior bevacizumab but no prior erlotinib, and six additional patients (18\%) had received prior erlotinib and bevacizumab (five patients received prior sequential erlotinib and bevacizumab; one patient received prior concurrent erlotinib and bevacizumab). No patients had previously received cetuximab. Of seven patients who received prior erlotinib but no prior bevacizumab, two (29\%) had SD $\geq 6$ months/ uPR. Of the five patients who received prior bevacizumab 
Table 1: Treatment-related Grade 2-4 adverse events observed in $\geq 5 \%$ of patients

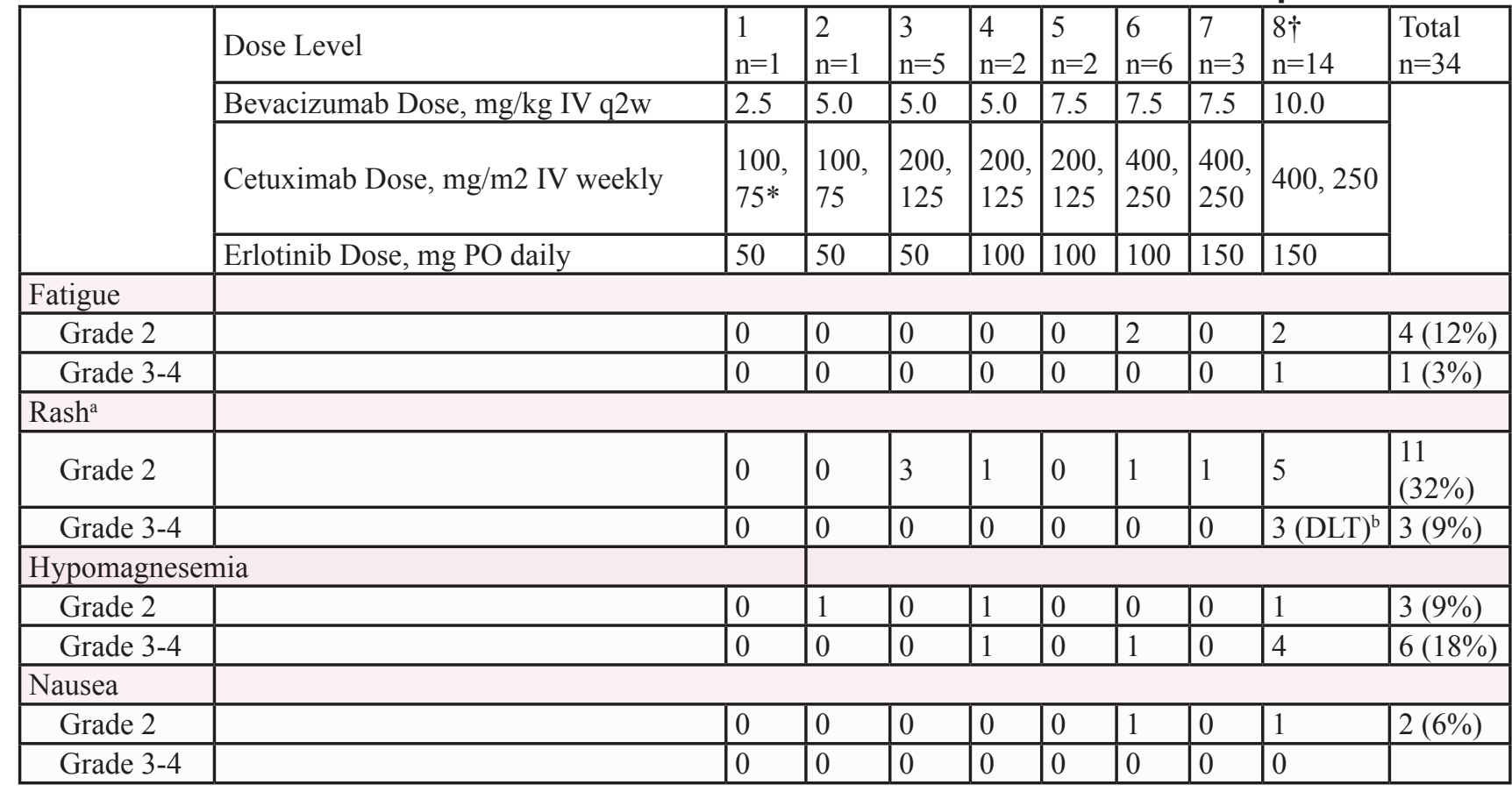

Abbreviations: DLT, dose-limiting toxicity; IV, intravenous; po, orally; q2w, every 2 weeks

'Recommended Phase II dose[33] (full approved doses of each drug).

${ }^{*}$ Cetuximab dose shown as loading dose, maintenance dose.

${ }^{\text {a Including pruritis }}$

${ }^{b}$ One out of the three events was considered a DLT.

but no prior erlotinib, three (60\%) had $\mathrm{SD} \geq 6$ months/uPR. Of the six patients who had received both prior erlotinib and bevacizumab, two (33\%) achieved $\mathrm{SD} \geq 6$ months/PR. The patient who received prior concurrent erlotinib and bevacizumab did not achieve $\mathrm{SD} \geq 6$ months/PR.

Of the 11 patients with $\mathrm{SD} \geq 6$ months/PR/uPR, four $(36 \%)$ had prior EGFR inhibitor treatment (two with erlotinib alone and two with prior sequential erlotinib and bevacizumab), five ( $45 \%$ ) had prior bevacizumab (three with bevacizumab alone and two with prior sequential erlotinib and bevacizumab), and four (36\%) had neither prior erlotinib or bevacizumab (Table 3). Prior EGFR and/or antiangiogenic treatment did not preclude $\mathrm{SD} \geq 6$ months/PR/uPR.

Among the four patients with $\mathrm{SD} \geq 6$ months/PR/uPR who had received prior erlotinib, one patient had primary resistance to erlotinib alone, having developed progression after two months of erlotinib (Table 3, patient \#146). Three patients $(75 \%)$ received the combination treatment for as long or longer than the duration of the prior erlotinib (Table 3, patients \#197, 90, and 146) (2, 5, and 13 months, respectively, with initial erlotinib treatment, and 6,9, and 14 months, respectively, with the combination treatment). Overcoming primary resistance to erlotinib and achieving a longer duration of treatment with this combination was demonstrated.

\section{Brain Metastases and Response}

Of 11 patients with brain metastases, three achieved a $\mathrm{PR} / \mathrm{uPR}$, and three had $\mathrm{SD} \geq 6$ months (total six of 11 , $54 \%$ ) (Table 3). One of these patients had five small, untreated brain metastases and achieved complete resolution of the brain tumors. The presence of brain metastases did not preclude $\mathrm{SD} \geq 6$ months/PR/uPR.

\section{Smoking History and Response}

Twenty-three $(68 \%)$ of the patients had a history of smoking. Of these 23 patients, two (9\%) achieved a $\mathrm{PR} / \mathrm{uPR}$, and five (22\%) had stable disease $\mathrm{SD} \geq 6$ months (total $=31 \%$ ), including one patient who was treated for 25 months (Table 3). Of the 11 patients (32\%) that did not have a history of smoking, two achieved a PR/uPR, and two had $\mathrm{SD} \geq 6$ months (total=36\%) (Table 3). Smoking history did not preclude $\mathrm{SD} \geq 6$ months/PR/uPR.

\section{Dosing and Response}

Of 17 patients on dose levels 7 or 8 , six $(35 \%)$ achieved $\mathrm{SD} \geq 6$ months/PR/uPR. For patients treated at dose levels 1-6, five of 17 (29\%) achieved $\mathrm{SD} \geq 6$ months/ PR (Table 1 and Figure 1). The only patient treated on 
Table 2: Patient Demographics

\begin{tabular}{|c|c|}
\hline \multicolumn{2}{|l|}{ Characteristics $(n=34)$} \\
\hline Age (years) & \\
\hline Median & 62 \\
\hline Range & $27-78$ \\
\hline \multicolumn{2}{|l|}{ Gender, n (\%) } \\
\hline Men & $18(53 \%)$ \\
\hline Women & $16(47 \%)$ \\
\hline \multicolumn{2}{|l|}{ Histologies, n (\%) } \\
\hline Adenocarcinoma & $26(76 \%)$ \\
\hline Squamous cell & $3(9 \%)$ \\
\hline Mucinous adenocarcinoma & $2(6 \%)$ \\
\hline Poorly differentiated carcinoma & $2(6 \%)$ \\
\hline Sarcomatoid carcinoma & $1(3 \%)$ \\
\hline \multicolumn{2}{|l|}{ No. of prior systemic therapies, $\mathrm{n}(\%)$} \\
\hline Median & 4 \\
\hline Range & $1-8$ \\
\hline Prior bevacizumab, n (\%) & $11(32 \%)$ \\
\hline Prior EGFR inhibitors, n (\%) & $13(38 \%)$ \\
\hline \multicolumn{2}{|l|}{ EGFR mutations, $\mathrm{n}(\%)$} \\
\hline Positive & $3(9 \%)$ \\
\hline Negative & $16(47 \%)$ \\
\hline Unknown & $15(44 \%)$ \\
\hline \multicolumn{2}{|l|}{ KRAS mutations, n (\%) } \\
\hline Positive & $0(0 \%)$ \\
\hline Negative & $19(56 \%)$ \\
\hline Unknown & $15(44 \%)$ \\
\hline History of smoking & $23(68 \%)$ \\
\hline History of brain metastases & $11(32 \%)$ \\
\hline \multicolumn{2}{|c|}{\begin{tabular}{|l|l|} 
ECOG performance status score, $\mathrm{n}(\%)$ & \\
\end{tabular}} \\
\hline 0 & $2(6 \%)$ \\
\hline 1 & $31(91 \%)$ \\
\hline 2 & $1(3 \%)$ \\
\hline $\begin{array}{lll}\text { Abbreviations: } & \text { ECOG, } & \text { Eastern } \\
\text { Oncology Group } & & \\
\end{array}$ & Cooperative \\
\hline
\end{tabular}

dose level 2 was stable for 6 months; two of the five patients treated on dose level 3 achieved $\mathrm{SD} \geq 6$ months/ PR. There was no obvious dose-response correlation, although the number of patients was small.

\section{Molecular Aberrations and Responses}

Of 16 patients with documented wild-type EGFR, five $(31 \%)$ had $S D \geq 6$ months or uPR. Three of 19 patients tested for EGFR aberrations showed an abnormality, and one of the three patients, with an activating L858R mutation [35] and a G873E mutation, had a PR. This patient also demonstrated a co-existing PIK3CA mutation and had received prior sequential erlotinib and bevacizumab; on the current study, the patient has achieved a 55\% regression and received treatment for 14 months. The other two patients with EGFR aberrations (exon 20 insertion and exon 19 deletion) demonstrated $20 \%$ and $11 \%$ regression, respectively, as best response, but the regressions were short -2 and 4 months on treatment, respectively. The presence of wild-type EGFR did not preclude achieving $\mathrm{SD} \geq 6$ months/uPR.

The only patient tested for $\mathrm{p} 53$ mutations had an R196* nonsense mutation. This patient achieved a $22 \%$ regression lasting 25 months.

Two of the nine total patients tested demonstrated PIK3CA mutations. One had an E542K mutation (with concomitant EGFR mutation) and had a 55\% regression, as mentioned above. The other patient, with an E545K mutation, had a $28 \%$ decrease (treatment duration $=4$ months). The presence of PIK3CA mutations did not preclude response.

Three patients were tested for PTEN loss, and in all patients, PTEN expression was normal. While PTEN loss can reflect a genetic aberration in NSCLC [36], the two patients tested for PTEN mutation were wild-type.

\section{Toxicity and Response}

Rash was the most frequently observed toxicity in patients (Table 1); 11 patients experienced grade 2 rash, of whom five (45\%) achieved $\mathrm{SD} \geq 6$ months/PR/uPR. Two of three patients with grade 3 rash or higher achieved $\mathrm{SD} \geq 6$ months/uPR (Table 3). Of 20 patients with grade 1 or no rash, four (20\%) achieved SD $\geq 6$ months/PR/uPR. Patients with higher grade rash were significantly more likely to have $\mathrm{SD} \geq 6$ months/PR/uPR (Spearman's correlation coefficient, $\mathrm{p}<0.01$ ).

\section{DISCUSSION}

In this study, we report the results of the cohort of patients with NSCLC treated on a phase I doseescalation trial of combination bevacizumab, cetuximab, and erlotinib. The rationale for this combination was: (1) preclinical and clinical studies that suggested increased activity when erlotinib was combined with bevacizumab [30, 31]; (2) preclinical studies indicating that EGFR signals through both kinase-dependent and -independent pathways [17]; and (3) studies demonstrating that combining an EGFR kinase inhibitor with EGFR antibodies was synergistic in animal models $[18,19]$.

This combination of drugs was well-tolerated. The RP2D was determined to be the full FDA-approved doses for all three drugs [34], and 13 of the 14 patients (93\%) treated at the RP2D tolerated treatment without drugrelated dose-limiting effects.

This regimen demonstrated antitumor activity in patients with NSCLC, including 11 patients (32\%) who had a best overall response of $\mathrm{SD} \geq 6$ months $(\mathrm{n}=7)$ or PR $(\mathrm{n}=4)$ (two PRs were unconfirmed). $\mathrm{SD} \geq 6$ months/PR/uPR were observed even in patients who had received prior 
bevacizumab and/or erlotinib, those with brain metastases, smokers, and patients treated at lower dose levels, so these characteristics do not preclude antitumor activity.

Remarkably, patients who previously had failed erlotinib also achieved $\mathrm{SD} \geq 6$ months/PR/uPR. In fact, overcoming primary resistance to erlotinib and achieving a longer duration of treatment with this combination than with prior erlotinib alone was demonstrated. Recent preclinical studies suggest that combining EGFR kinase inhibitors and anti-EGFR antibodies may be more effective than either alone, perhaps because EGFR is able to maintain cancer cell survival independent of its kinase activity [17-19]. The clinical data presented here also support combining kinase inhibitors and antibodies.

Previous phase I/II clinical studies combining cetuximab and erlotinib in patients with NSCLC failed to show significant tumor regression [28]. In contrast, as mentioned above, four patients on our study achieved a PR/uPR. The reason for this difference is unclear but could be due to the addition of bevacizumab in our regimen or because almost half of the patients treated on the prior study (but none in our study) had a known EGFR resistance mutation $[37,38]$. It is important to use caution comparing the previous study to the results presented here because the previous study was conducted in a select group of patients, i.e., only patients with NSCLC who had received erlotinib throughout one month prior to enrollment and who had clinically-defined erlotinib resistance.

Prior studies combining erlotinib and bevacizumab showed PR/CR rates of $18-20 \%$ and improved PFS, but no improvement in OS, supporting a potential role for bevacizumab $[32,33]$. However, these results cannot be compared directly with those in our study because patients in the prior studies were less heavily pretreated (median 1-2 prior systemic regimens versus four in our study) and both prior studies excluded patients who had received previous EGFR or VEGF inhibitors.

The presence of brain metastases did not compromise the rate of $\mathrm{SD} \geq 6$ months/PR/uPR. Five of 11 patients with brain metastases achieved $\mathrm{SD} \geq 6$ months/PR/ $\mathrm{UPR}$, and one individual showed complete resolution of her brain metastases. No patient had intracranial hemorrhage. These results suggest that patients with NSCLC and brain metastases can safely receive this regimen and that it has activity, which is consistent with a previous studies on the

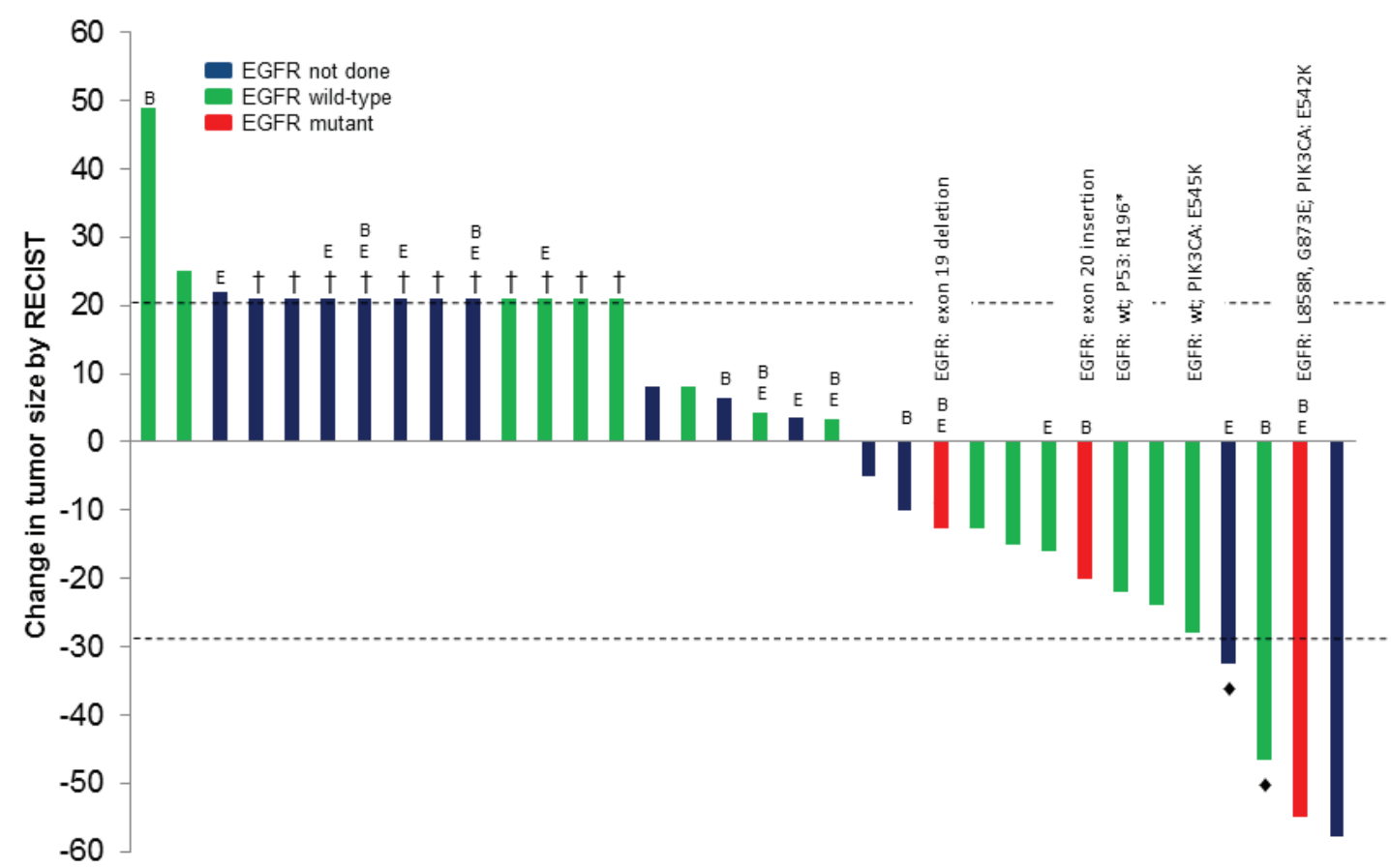

\begin{tabular}{|c|c|c|c|c|c|c|c|c|c|c|c|c|c|c|c|c|c|c|c|c|c|c|c|c|c|c|c|c|c|c|c|c|c|c|}
\hline Dose Level & 6 & 8 & 6 & 3 & 3 & 5 & 6 & 7 & 7 & 8 & 4 & 1 & 5 & 7 & 2 & 8 & 8 & 8 & 8 & 6 & 3 & 4 & 8 & 6 & 8 & 6 & 8 & 3 & 8 & 8 & 8 & 8 & 8 & 3 \\
\hline Months on & 2 & 2 & 2 & 2 & 1 & 5 & 1 & 1 & 1 & 1 & 2 & 2 & 1 & 4 & 6 & 2 & 12 & 6 & 4 & 4 & 2 & 7 & 4 & 4 & 3 & 9 & & 25 & 10 & 4 & 6 & 4 & 14 & 0 \\
\hline
\end{tabular}

Figure 1: Best response in all 34 NSCLC treated. Patients with early clinical progression, new lesions, or who withdrew early are indicated arbitrarily as $+21 \%$ and denoted by $\uparrow$. Unconfirmed PRs are indicated by $\$$. Patients who received prior bevacizumab are denoted by "B", and patients who received prior erlotinib are denoted by "E". No patients had cetuximab. Patients with wild-type EGFR are shown in green; patients with EGFR alterations are shown in red; and patients that were not tested for EGFR mutations are shown in blue. The specific mutation in EGFR, PIK3CA, and/or p53 is labeled for all patients that had mutations in one or more genes tested. The dose level and treatment duration (months) for each patient are shown in the table below. 
Table 3: Characteristics for patients with any tumor regression or $\mathrm{SD} \geq 6$ months $(\mathrm{n}=17)$

\begin{tabular}{|c|c|c|c|c|c|c|c|c|c|c|c|c|}
\hline Case \# & Histology & \begin{tabular}{|l} 
Best \\
Response \%
\end{tabular} & \begin{tabular}{|l|} 
Months \\
on \\
study
\end{tabular} & Smoker & EGFR & PIK3CA & $\mathrm{p} 53$ & $\begin{array}{l}\text { Prior EGFR } \\
\text { Tx }\end{array}$ & $\begin{array}{l}\text { Prior } \\
\text { bevacizumab }\end{array}$ & \begin{tabular}{|l} 
Brain \\
metastases
\end{tabular} & $\begin{array}{l}\text { Dose } \\
\text { Level }\end{array}$ & $\begin{array}{l}\text { Rash } \\
\text { Grade } \\
>3\end{array}$ \\
\hline \multicolumn{13}{|l|}{ PR } \\
\hline 37 & Adenocarcinoma & -59 & 10 & $\mathrm{Y}$ & ND & ND & ND & $\mathrm{N}$ & $\mathrm{N}$ & $\mathrm{Y}$ & 3 & $\mathrm{~N}$ \\
\hline 197 & Mod. diff. adeno. & -55 & 14 & $\mathrm{~N}$ & $\begin{array}{l}\text { L858R } \\
\text { G873E }\end{array}$ & E542K & ND & \begin{tabular}{|l|} 
Erlotinib \\
$(13$ months $)$
\end{tabular} & $\mathrm{Y}$ & $\mathrm{Y}$ & 8 & $\mathrm{~N}$ \\
\hline 200 & $\begin{array}{l}\text { Poorly-mod. diff. } \\
\text { adeno. }\end{array}$ & -48 & 4 & $\mathrm{Y}$ & NEG & NEG & ND & $\mathrm{N}$ & Y & $\mathrm{Y}$ & 8 & $\mathrm{Y}$ \\
\hline 226 & Adenocarcinoma & -34 & 6 & $\mathrm{~N}$ & ND & ND & ND & \begin{tabular}{|l} 
Erlotinib \\
$(10$ months $)$
\end{tabular} & $\mathrm{N}$ & $\mathrm{N}$ & 8 & $\mathrm{~N}$ \\
\hline \multicolumn{13}{|c|}{$\mathrm{SD} \geq 6$ Months } \\
\hline 153 & \begin{tabular}{|ll} 
Poorly & diff. \\
adeno. & with \\
mucin & \\
\end{tabular} & -24 & 10 & $\mathrm{~N}$ & NEG & NEG & ND & $\mathrm{N}$ & $\mathrm{N}$ & $\mathrm{N}$ & 8 & Y \\
\hline 39 & SCC & -22 & 25 & $\mathrm{Y}$ & NEG & NEG & R196* & $\mathrm{N}$ & $\mathrm{N}$ & $\mathrm{N}$ & 3 & $\mathrm{~N}$ \\
\hline 90 & Mucinous adeno & -16 & 9 & $\mathrm{~N}$ & NEG & NEG & ND & $\begin{array}{l}\text { Erlotinib } \\
\text { (5 months) }\end{array}$ & $\mathrm{N}$ & $\mathrm{N}$ & 6 & $\mathrm{~N}$ \\
\hline 45 & Adenocarcinoma & -10 & 7 & $\mathrm{Y}$ & $\mathrm{ND}$ & ND & $\mathrm{ND}$ & $\mathrm{N}$ & $\mathrm{Y}$ & $\mathrm{Y}$ & 4 & $\mathrm{~N}$ \\
\hline 146 & Adenocarcinoma & 5 & 6 & $\mathrm{Y}$ & NEG & NEG & ND & $\begin{array}{l}\text { Erlotinib } \\
(2 \text { months })\end{array}$ & $\mathrm{Y}$ & $\mathrm{Y}$ & 8 & $\mathrm{~N}$ \\
\hline 169 & Adenocarcinoma & 7 & 12 & $\mathrm{Y}$ & ND & ND & ND & $\mathrm{N}$ & $\mathrm{Y}$ & $\mathrm{Y}$ & 8 & $\mathrm{~N}$ \\
\hline 28 & Adenocarcinoma & 8 & 6 & $\mathrm{Y}$ & $\mathrm{ND}$ & ND & $\mathrm{ND}$ & $\mathrm{N}$ & $\mathrm{N}$ & $\mathrm{N}$ & 2 & $\mathrm{~N}$ \\
\hline \multicolumn{13}{|c|}{ SD $<6$ Months and tumor decrease $0-29 \%$} \\
\hline 228 & Adenocarcinoma & -28 & 4 & $\mathrm{Y}$ & NEG & E545K & $\mathrm{ND}$ & $\mathrm{N}$ & $\mathrm{N}$ & $\mathrm{N}$ & 8 & $\mathrm{~N}$ \\
\hline 148 & Adenocarcinoma & -20 & 2 & $\mathrm{~N}$ & \begin{tabular}{|l|} 
Exon 20 \\
insertion
\end{tabular} & ND & ND & $\mathrm{N}$ & $\mathrm{Y}$ & $\mathrm{N}$ & 8 & $\mathrm{Y}$ \\
\hline 207 & Adenocarcinoma & -15 & 3 & $\mathrm{Y}$ & NEG & NEG & ND & $\mathrm{N}$ & $\mathrm{N}$ & $\mathrm{N}$ & 8 & $\mathrm{~N}$ \\
\hline 89 & \begin{tabular}{|ll} 
Poorly diff. \\
adeno.
\end{tabular} & -13 & 4 & $\mathrm{Y}$ & NEG & ND & ND & $\mathrm{N}$ & $\mathrm{N}$ & $\mathrm{N}$ & 6 & $\mathrm{~N}$ \\
\hline 181 & Adenocarcinoma & -11 & 4 & $\mathrm{Y}$ & $\begin{array}{l}\text { Exon 19 } \\
\text { deletion }\end{array}$ & ND & ND & $\begin{array}{l}\text { Erlotinib } \\
(12 \text { months })\end{array}$ & $\mathrm{Y}$ & $\mathrm{N}$ & 8 & $\mathrm{~N}$ \\
\hline 40 & Adenocarcinoma & -5 & 2 & $\mathrm{Y}$ & ND & ND & ND & $\mathrm{N}$ & $\mathrm{N}$ & $\mathrm{Y}$ & 3 & $\mathrm{~N}$ \\
\hline
\end{tabular}

Abbreviations: adeno, adenocarcinoma; diff, differentiated; mod, moderately; ND, not done; NEG, negative; PR, partial response; SCC, squamous cell carcinoma; SD; stable disease; Tx, treatment

४ Indicates an unconfirmed PR.

efficacy of TKIs against brain metastases in NSCLC [39].

$\mathrm{SD} \geq 6$ months/PR/uPR were observed even at low dose levels. No dose-related difference was observed in the number of patients who achieved $\mathrm{SD} \geq 6$ months/PR/ uPR (six of 17 patients at dose levels 7-8 versus five of 17 patients at dose levels 1-6). These data are consistent with a previous study of 683 patients receiving treatment on phase I trials in our department which found that patients who received lower doses of predominantly targeted agents fared as well as those receiving higher doses [40].

Exploratory analysis of molecular aberrations was performed to identify potential subsets of patients with $\mathrm{SD} \geq 6$ months/PR/uPR. EGFR, PIK3CA, PTEN, and p53 mutation data were available for 20 patients, including patients who had PTEN assessed by immunohistochemistry. Although the limited number of patients prevents definitive conclusions, it was noted that all five patients with molecular aberrations (EGFR mutations L848R and G873E and PIK3CA mutation E542K ( $\mathrm{n}=1)$, EGFR exon 20 insertion $(\mathrm{n}=1)$, EGFR exon 19 deletion $(n=1)$, p53 mutation ( $\mathrm{n}=1)$, PIK3CA mutation $(\mathrm{n}=1)$ ) experienced tumor regression, which in some cases was prolonged.

Of special interest, out of 16 patients with documented wild-type EGFR, five (31\%) achieved $\mathrm{SD} \geq 6$ months/uPR. Although EGFR mutations are generally found in lung cancer patients who are non-smokers [41], seven of 23 smokers (30\%) achieved $\mathrm{SD} \geq 6$ months/PR/ uPR. These data suggest that wild-type EGFR and/or a history of smoking did not preclude salutary effects with this regimen.

In regard to toxicity, previous studies have shown a correlation between rash and response to EGFR inhibitors [42]. In our study, patients who had higher grade rash were more likely to have $\mathrm{SD} \geq 6$ months/PR/uPR $(\mathrm{p}<0.01)$. In previous studies of metastatic colorectal cancer combining bevacizumab, cetuximab, and cytotoxic chemotherapy, the addition of cetuximab shortened progression-free survival $[43,44]$. In contrast, our trial combined bevacizumab and cetuximab without chemotherapy. Future studies should be pursued to further investigate this combination without chemotherapy.

Despite the promising responses observed in our study, most patients developed progressive disease, which 
may be explained by multiple potential mechanisms of resistance [45-47]. Future studies should be considered to further investigate causes of resistance in the clinical setting.

In conclusion, the results presented here demonstrate that dual inhibition of EGFR with erlotinib and cetuximab, combined with the VEGF antibody bevacizumab, is welltolerated, allowing full doses of all three drugs in patients with NSCLC. $\mathrm{SD} \geq 6$ months/PR/uPR was achieved in $32 \%$ of this heavily pretreated patient population, including patients with brain metastases, smokers, those treated at lower doses, those with prior erlotinib and/or bevacizumab, and those with wild-type EGFR. These results suggest that this regimen merits further investigation.

\section{A}

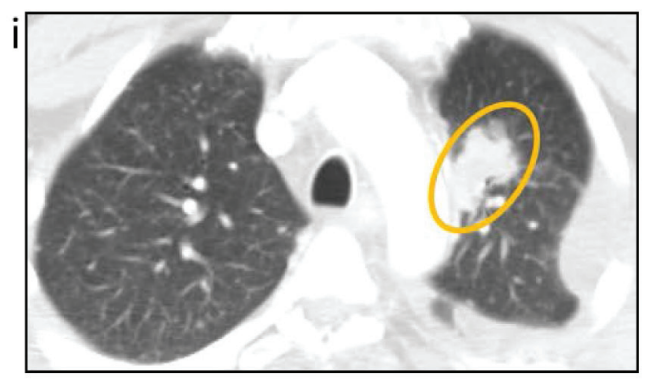

B
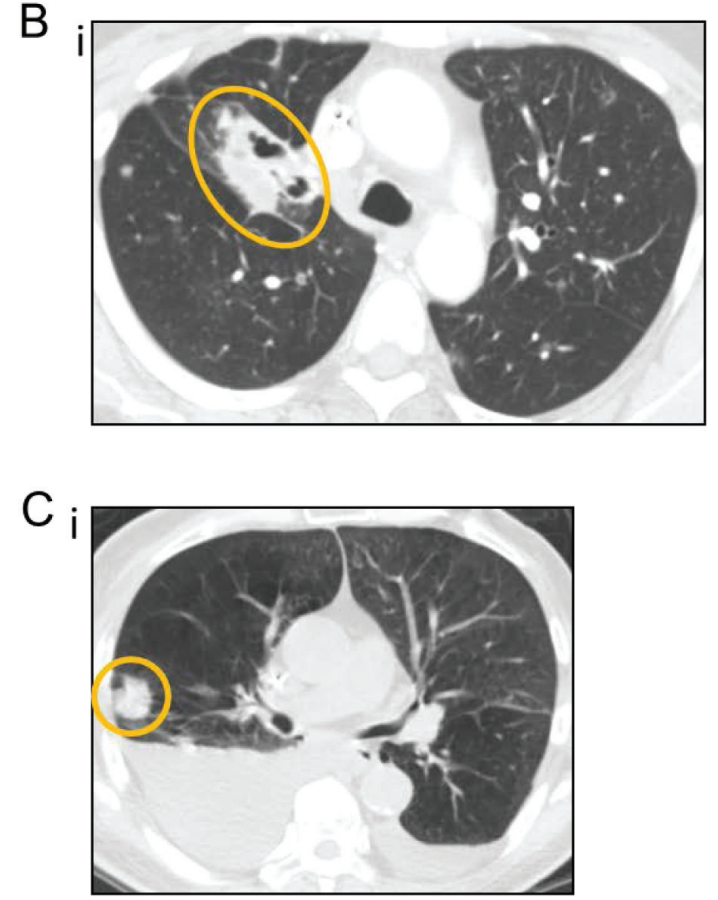

\section{METHODS}

\section{Study Design}

The study was conducted at The University of Texas M. D. Anderson Cancer Center (MDACC) per Institutional Review Board guidelines. The lung cancer cohort reported herein included all patients with NSCLC who started therapy between 4/7/2008 and 12/27/2010 as part of a dose-escalation study conducted in patients with advanced cancer. The dose escalation portion of the study determined the recommended phase II dose (RP2D) to be bevacizumab $10 \mathrm{mg} / \mathrm{kg}$ IV every two weeks; cetuximab loading $400 \mathrm{mg} / \mathrm{m}^{2}$, maintenance $250 \mathrm{mg} / \mathrm{m}^{2} \mathrm{IV}$ weekly; and erlotinib $150 \mathrm{mg}$ PO daily [34]. A cycle was 28 days. Patients were treated at variable dose levels, depending on the time of study entry (Table 1).
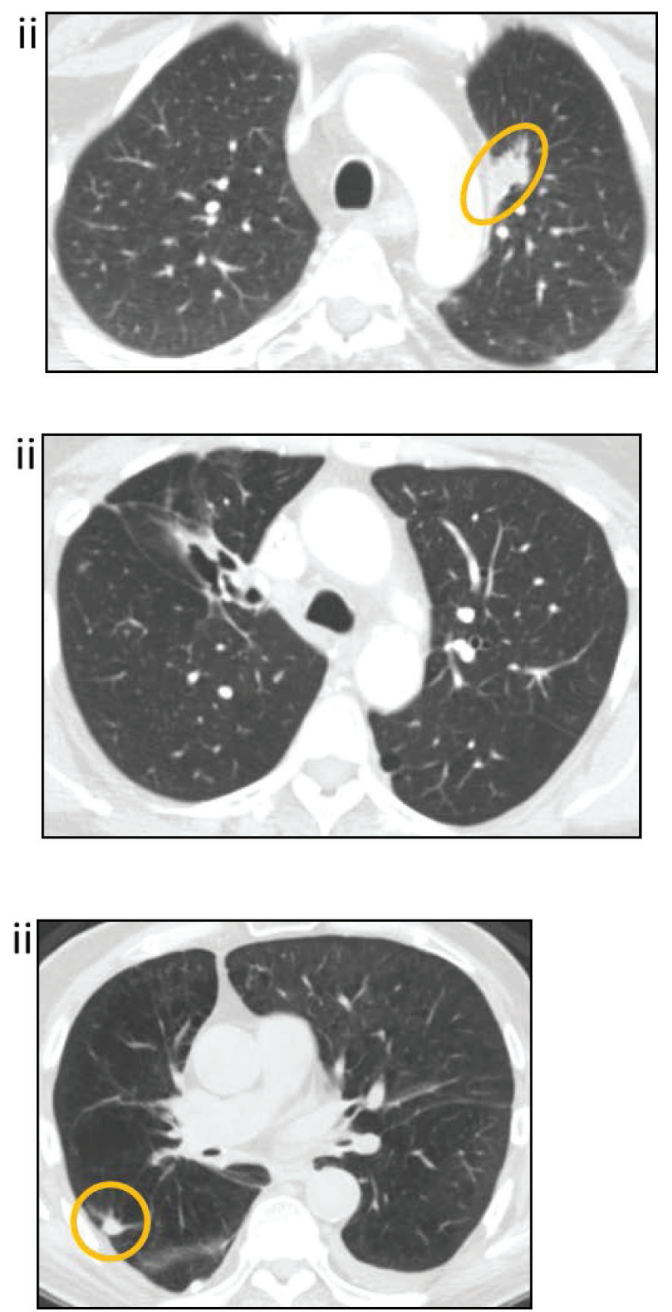

Figure 2: Computed tomography (CT) images of the three patients with the greatest tumor reduction. (A) patient $\# 37$ (EGFR mutation not done, smoker), who achieved a PR (59\% decrease), at baseline (i) and 32 weeks (ii), (B) patient \#197 (EGFR L858R, G873E and PIK3CA E542K mutations, nonsmoker) who achieved a PR (55\% decrease), at baseline (i) and 20 weeks (ii), and (C) patient \#200 (EGFR wild-type, smoker), who achieved an unconfirmed PR (48\% decrease), at baseline (i) and 8 weeks (ii). 


\section{Patients}

Patients had metastatic or advanced NSCLC not amendable to standard therapy, an Eastern Cooperative Oncology Group (ECOG) performance status 0-2 [48], and adequate hematologic, hepatic, and renal function. Exclusion criteria included hemoptysis, unexplained bleeding, significant cardiovascular disease, intercurrent uncontrolled illness, significant gastrointestinal bleeding within 28 days, hemorrhagic brain metastases, prior abdominal surgery within 30 days, pregnancy, and a history of hypersensitivity to bevacizumab, cetuximab, and/or erlotinib. Treatment with prior cytotoxic therapies must have ended at least three weeks prior to enrollment, and biologic therapy must have ended at least two weeks or five drug half-lives prior to enrollment (whichever is shorter).

\section{Safety}

Clinically significant adverse events were assessed according to the National Cancer Institute Common Terminology Criteria for Adverse Events (NCI CTCAE), version 3.0. History, physical exam, hematology, blood chemistry, and urinalysis were performed at baseline and regular intervals while receiving treatment.

\section{Evaluation of Efficacy}

Treatment efficacy was evaluated by diagnostic imaging per Response Evaluation Criteria in Solid Tumors (RECIST) 1.0 [49]. Radiologic assessments were conducted at baseline and about every 8 weeks thereafter.

\section{Molecular Testing}

EGFR, KRAS, PIK3CA, p53, and PTEN mutation analysis, as well as PTEN expression by immunohistochemistry, were performed in the Clinical Laboratory Improvement Amendments (CLIA)-approved M.D. Anderson Cancer Center laboratory for patients with available archived tissue. For EGFR (exons 18-21 of the kinase domain), KRAS (codons 12, 13 and 61), PIK3CA (codons 532-554 in exon 9 and codons 1011-1062 in exon 20), p53 (exons 4-9), and PTEN mutation (exons 1-9 (entire coding sequence)) testing, PCR-based sequencing analysis was performed on DNA extracted from paraffinembedded tumor tissue. The lower limit of detection was approximately one cell bearing the mutation per five to ten normal cells. PTEN expression was determined by immunohistochemistry using anti-PTEN monoclonal mouse antibody (Dako, Carpinteria, CA).

\section{Statistical Analysis}

No formal hypotheses were tested, and analyses were descriptive and exploratory. Non-parametric correlations were determined with Spearman's rank correlation coefficient.

\section{Conflict of Interest:}

All authors with exception of Razelle Kurzrock have no competing interests that might be perceived to influence the content of this article. Dr. Kurzrock received grant/research support from Genentech and Roche.

\section{ACKNOWLEDGEMENTS}

This research was supported by a Career Development Award for Clinical Oncology, CA088084 from the National Institutes of Health and the National Cancer Institute to Paul Calabresi. We would like to thank the patients and their families. We also thank Adrienne Howard for regulatory protocol assistance.

\section{REFERENCES}

1. Voldborg BR, Damstrup L, Spang-Thomsen M, Poulsen HS. Epidermal growth factor receptor (EGFR) and EGFR mutations, function and possible role in clinical trials. Ann Oncol 1997; 8: 1197-1206.

2. Normanno N, De Luca A, Bianco C, Strizzi L, Mancino M, Maiello MR, Cartenuto A, De Feo G, Caponigro F, Salomon DS. Epidermal growth factor receptor (EGFR) signaling in cancer. Gene 2006; 366: 2-16.

3. Eberhard DA, Johnson BE, Amler LC, Goddard AD, Heldens SL, Herbst RS, Ince WL, Jänne PA, Januario T, Johnson DH, Klein P, Miller VA, Ostland MA, Raimes DA, et al. Mutations in the epidermal growth factor receptor and in KRAS are predictive and prognostic indicators in patients with non-small-cell lung cancer treated with chemotherapy alone and in combination with erlotinib. J Clin Oncol 2005; 23: 5900-5909.

4. Paez JG, Jänne PA, Lee JC, Tracy S, Greulich H, Gabriel S, Herman P, Kaye FJ, Lindeman N, Boggon TJ, Naoki K, Sasaki H, Fujii Y, Eck MJ, et al. EGFR mutations in lung cancer: correlation with clinical response to gefitinib therapy. Science 2004; 304: 1497-1500.

5. Dienstmann R, Martinez P, Felip E. Personalizing therapy with targeted agents in non-small cell lung cancer. Oncotarget. 2011 Mar;2(3):165-77.

6. Janku F, Stewart DJ, Kurzrock R. Targeted therapy in nonsmall-cell lung cancer-is it becoming a reality? Nat Rev Clin Oncol 8: 384.

7. Janku F, Garrido-Laguna I, Petruzelka LB, Stewart DJ, Kurzrock R. Novel therapeutic targets in non-small cell 
lung cancer. J Thorac Oncol 2011; 6: 1601-1612.

8. Janku F, Tsimberidou AM, Wang X, Hong DS, Naing A, Gong J, Garrido-Laguna I, Parsons HA, Zinner RG, Kurzrock R. Outcomes of patients with advanced non-small cell lung cancer treated in a phase I clinic. Oncologist 2011; 16: 327-335.

9. US Food and Drug Administration. Drugs@FDA: FDA approved drug products. http://www.accessdata.fda.gov/ SCRIPTS/CDER/DRUGSATFDA/INDEX.CFM (30 May 2012, date last accessed).

10. Pao W, Miller V, Zakowski M, Doherty J, Politi K, Sarkaria I, Singh B, Heelan R, Rusch V, Fulton L, Mardis E, Kupfer D, Wilson R, Kris M, Varmus H. EGF receptor gene mutations are common in lung cancers from "never smokers" and are associated with sensitivity of tumors to gefitinib and erlotinib. Proc Natl Acad Sci U S A 2004; 101: 13306-13311.

11. Johnson BE, Lucca J, Rabin MS, Lynch TJ, Ostler P, Skarin AT, Temel J, Liu G, Janne PA, Dana Farber Cancer Institute, Boston, MA; Massachusetts General Hospital, Boston, MA. Preliminary results from a phase II study of the epidermal growth factor receptor tyrosine kinase inhibitor erlotinib in patients $>70$ years of age with previously untreated advanced non-small cell lung carcinoma. JCO 2004; 22: abstr 7080.

12. Seike M, Gemma A. Diagnostic and therapeutic biomarkers for lung cancer patients. Nihon Rinsho 2012; 70: 809-815.

13. Kancha RK, Peschel C, Duyster J. The epidermal growth factor receptor-L861Q mutation increases kinase activity without leading to enhanced sensitivity toward epidermal growth factor receptor kinase inhibitors. J Thorac Oncol 6: 387-392.

14. Zhou C, Wu YL, Chen G, Feng J, Liu XQ, Wang C, Zhang S, Wang J, Zhou S, Ren S, Lu S, Zhang L, Hu C, Hu C, et al. Erlotinib versus chemotherapy as first-line treatment for patients with advanced EGFR mutation-positive non-smallcell lung cancer (OPTIMAL, CTONG-0802): a multicentre, open-label, randomised, phase 3 study. Lancet Oncol 2011; 12: 735-742.

15. Greulich H, Chen TH, Feng W, Jänne PA, Alvarez JV, Zappaterra M, Bulmer SE, Frank DA, Hahn WC, Sellers WR, Meyerson M. Oncogenic transformation by inhibitorsensitive and -resistant EGFR mutants. PLoS Med 2005; 2: e313.

16. Pirker R, Pereira JR, Szczesna A, von Pawel J, Krzakowski M, Ramlau R, Vynnychenko I, Park K, Yu CT, Ganul V, Roh JK, Bajetta E, O'Byrne K, de Marinis F, et al. Cetuximab plus chemotherapy in patients with advanced non-small-cell lung cancer (FLEX): an open-label randomised phase III trial. Lancet 2009; 373: 1525-1531.

17. Weihua Z, Tsan R, Huang WC, Wu Q, Chiu CH, Fidler IJ, Hung MC. Survival of cancer cells is maintained by EGFR independent of its kinase activity. Cancer Cell 2008; 13: 385-393.
18. Matar P, Rojo F, Cassia R, Moreno-Bueno G, Di Cosimo S, Tabernero J, Guzmán M, Rodriguez S, Arribas J, Palacios J, Baselga J. Combined epidermal growth factor receptor targeting with the tyrosine kinase inhibitor gefitinib (ZD1839) and the monoclonal antibody cetuximab (IMC-C225): superiority over single-agent receptor targeting. Clin Cancer Res 2004; 10: 6487-6501.

19. Huang S, Armstrong EA, Benavente S, Chinnaiyan P, Harari PM. Dual-agent molecular targeting of the epidermal growth factor receptor (EGFR): combining anti-EGFR antibody with tyrosine kinase inhibitor. Cancer Res 2004; 64: 5355-5362.

20. Graham J, Muhsin M, Kirkpatrick P. Cetuximab. Nat Rev Drug Discov 2004; 3: 549-550.

21. Perez-Torres M, Guix M, Gonzalez A, Arteaga CL. Epidermal growth factor receptor (EGFR) antibody downregulates mutant receptors and inhibits tumors expressing EGFR mutations. J Biol Chem 2006; 281: 40183-40192.

22. Holash J, Maisonpierre PC, Compton D, Boland P, Alexander CR, Zagzag D, Yancopoulos GD, Weigand SJ. Vessel cooption, regression, and growth in tumors mediated by angiopoietins and VEGF. Science 1999; 284: 1994-1998.

23. Ferrara N, Kerbel RS. Angiogenesis as a therapeutic target. Nature 2005; 438: 967-974.

24. Sandler A, Gray R, Perry MC, Brahmer J, Schiller JH, Dowlati A, Lilenbaum R, Johnson DH. Paclitaxelcarboplatin alone or with bevacizumab for non-small-cell lung cancer. N Engl J Med 2006; 355: 2542-2550.

25. Roodink I, Leenders WP. Targeted therapies of cancer: angiogenesis inhibition seems not enough. Cancer Lett 299: $1-10$.

26. Ellis LM, Hicklin DJ. VEGF-targeted therapy: mechanisms of anti-tumour activity. Nat Rev Cancer 2008; 8: 579-591.

27. Liu S, Wang D, Chen B, Wang Y, Zhao W, Wu J. The safety and efficacy of EGFR TKIs monotherapy versus singleagent chemotherapy using third-generation cytotoxics as the first-line treatment for patients with advanced non-small cell lung cancer and poor performance status. Lung Cancer 2011; 73: 203-210.

28. Janjigian YY, Azzoli CG, Krug LM, Pereira LK, Rizvi NA, Pietanza MC, Kris MG, Ginsberg MS, Pao W, Miller VA, Riely GJ. Phase I/II trial of cetuximab and erlotinib in patients with lung adenocarcinoma and acquired resistance to erlotinib. Clin Cancer Res 17: 2521-2527.

29. Ramalingam S, Forster J, Naret C, Evans T, Sulecki M, Lu $\mathrm{H}$, Teegarden P, Weber MR, Belani CP. Dual inhibition of the epidermal growth factor receptor with cetuximab, an IgG1 monoclonal antibody, and gefitinib, a tyrosine kinase inhibitor, in patients with refractory non-small cell lung cancer (NSCLC): a phase I study. J Thorac Oncol 2008; 3: 258-264.

30. Lichtenberger BM, Tan PK, Niederleithner H, Ferrara N, Petzelbauer P, Sibilia M. Autocrine VEGF signaling synergizes with EGFR in tumor cells to promote epithelial 
cancer development. Cell 140: 268-279.

31. Tortora G, Ciardiello F, Gasparini G. Combined targeting of EGFR-dependent and VEGF-dependent pathways: rationale, preclinical studies and clinical applications. Nat Clin Pract Oncol 2008; 5: 521-530.

32. Herbst RS, Johnson DH, Mininberg E, Carbone DP, Henderson T, Kim ES, Blumenschein G Jr, Lee JJ, Liu DD, Truong MT, Hong WK, Tran H, Tsao Z, Xie D, et al. Phase I/II trial evaluating the anti-vascular endothelial growth factor monoclonal antibody bevacizumab in combination with the HER-1/epidermal growth factor receptor tyrosine kinase inhibitor erlotinib for patients with recurrent nonsmall-cell lung cancer. J Clin Oncol 2005; 23: 2544-2555.

33. Herbst RS, Ansari R, Bustin F, Flynn P, Hart L, Otterson GA, Vlahovic G, Soh CH, O'Connor P, Hainsworth J. Efficacy of bevacizumab plus erlotinib versus erlotinib alone in advanced non-small-cell lung cancer after failure of standard first-line chemotherapy (BeTa): a double-blind, placebo-controlled, phase 3 trial. Lancet 377: 1846-1854.

34. Falchook GS, Wheler JJ, Naing A, Hong DS, Moulder SL, Piha-Paul SA, Ng CS, Jackson E, Kurzrock R, University of Texas M.D. Anderson Cancer Center, Houston, TX. A phase I study of bevacizumab in combination with sunitinib, sorafenib, and erlotinib plus cetuximab, and trastuzumab plus lapatinib. J Clin Oncol 2010; 28: abstr 2512.

35. Gazdar AF. Activating and resistance mutations of EGFR in non-small-cell lung cancer: role in clinical response to EGFR tyrosine kinase inhibitors. Oncogene 2009; 28 Suppl 1: S24-31.

36. Marsit CJ, Zheng S, Aldape K, Hinds PW, Nelson HH, Wiencke JK, Kelsey KT. PTEN expression in nonsmall-cell lung cancer: evaluating its relation to tumor characteristics, allelic loss, and epigenetic alteration. Hum Pathol 2005; 36: 768-776.

37. Pao W, Miller VA, Politi KA, Riely GJ, Somwar R, Zakowski MF, Kris MG, Varmus H. Acquired resistance of lung adenocarcinomas to gefitinib or erlotinib is associated with a second mutation in the EGFR kinase domain. PLoS Med 2005; 2: e73.

38. Balak MN, Gong Y, Riely GJ, Somwar R, Li AR, Zakowski MF, Chiang A, Yang G, Ouerfelli O, Kris MG, Ladanyi M, Miller VA, Pao W. Novel D761Y and common secondary T790M mutations in epidermal growth factor receptormutant lung adenocarcinomas with acquired resistance to kinase inhibitors. Clin Cancer Res 2006; 12: 6494-6501.

39. Jamal-Hanjani M, Spicer J. Epidermal growth factor receptor tyrosine kinase inhibitors in the treatment of epidermal growth factor receptor-mutant non-small cell lung cancer metastatic to the brain. Clin Cancer Res 2012; 18: 938-944.

40. Jain RK, Lee JJ, Hong D, Markman M, Gong J, Naing A, Wheler J, Kurzrock R. Phase I oncology studies: evidence that in the era of targeted therapies patients on lower doses do not fare worse. Clin Cancer Res 16: 1289-1297.
41. Rosell R, Moran T, Queralt C, Porta R, Cardenal F, CampsC, Majem M, Lopez-Vivanco G, Isla D, Provencio M, Insa A, Massuti B, Gonzalez-Larriba JL, Paz-Ares $\mathrm{L}$, et al. Screening for epidermal growth factor receptor mutations in lung cancer. N Engl J Med 2009; 361: 958967.

42. Perez-Soler R, Chachoua A, Hammond LA, Rowinsky EK, Huberman M, Karp D, Rigas J, Clark GM, Santabárbara P, Bonomi P. Determinants of tumor response and survival with erlotinib in patients with non--small-cell lung cancer. J Clin Oncol 2004; 22: 3238-3247.

43. Saltz L, Badarinath S, Dakhil S, Bienvenu B, Harker WG, Birchfield G, Tokaz LK, Barrera D, Conkling PR, O'Rourke MA, Richards DA, Reidy D, Solit D, Vakiani E, et al. Phase III trial of cetuximab, bevacizumab, and 5-fluorouracil/ leucovorin vs. FOLFOX-bevacizumab in colorectal cancer. Clin Colorectal Cancer 2012; 11: 101-111.

44. Tol J, Koopman M, Cats A, Rodenburg CJ, Creemers GJ, Schrama JG, Erdkamp FL, Vos AH, van Groeningen CJ, Sinnige HA, Richel DJ, Voest EE, Dijkstra JR, VinkBörger ME, et al. Chemotherapy, bevacizumab, and cetuximab in metastatic colorectal cancer. N Engl J Med 2009; 360: 563-572.

45. Hoellein A, Pickhard A, von Keitz F, Schoeffmann S, Piontek G, Rudelius M, Baumgart A, Wagenpfeil S, Peschel C, Dechow T, Bier H, Keller U. Aurora kinase inhibition overcomes cetuximab resistance in squamous cell cancer of the head and neck. Oncotarget 2011; 2: 599-609.

46. Morris LG, Chan TA. Resistance to EGFR inhibitors: molecular determinants and the enigma of head and neck cancer. Oncotarget: 2011; 2: 894-895.

47. Zhang Z, Stiegler AL, Boggon TJ, Kobayashi S, Halmos B. EGFR-mutated lung cancer: a paradigm of molecular oncology. Oncotarget: 2010; 1: 497-514.

48. Oken MM, Creech RH, Tormey DC, Horton J, Davis TE, McFadden ET, Carbone PP. Toxicity and response criteria of the Eastern Cooperative Oncology Group. Am J Clin Oncol 1982; 5: 649-655.

49. Therasse P, Arbuck SG, Eisenhauer EA, Wanders J, Kaplan RS, Rubinstein L, Verweij J, Van Glabbeke M, van Oosterom AT, Christian MC, Gwyther SG. New guidelines to evaluate the response to treatment in solid tumors. European Organization for Research and Treatment of Cancer, National Cancer Institute of the United States, National Cancer Institute of Canada. J Natl Cancer Inst 2000; 92: 205-216. 